\title{
Promoting Aesthetical Values to Education
}

\author{
Marit Ulvik* \\ Department of Education, University of Bergen, Bergen, Norway
}

With a pressure on schools to meet the requirements of a knowledge-based global economy, human development, critical thinking and imagination seem to be given lower priority. This article argues for including the aesthetic dimension in teaching as a way to foster human development. While aesthetic subjects are cut, there is a growing interest in aesthetic methods through which students are expected to use their knowledge in new and creative ways. However, there is a tension involved in combining innovative and creative thinking with the objectives model, in which education is broken down into measurable targets. Including more than what is measurable is important to encourage students to not only copy what they are told, but to become creative and able to find their own solutions in the future. The aesthetic dimension might support independent thinking and imagination, crucial qualities in a democracy and for developing a future that we cannot yet see. Aesthetics is here understood in a broad sense and not limited

OPEN ACCESS

Edited by:

Ainat Guberman,

David Yellin College of Education,

Israel

Reviewed by:

Jodi Nickel,

Mount Royal University, Canada

Martha Prata- Linhares,

Universidade Federal do Triângulo

Mineiro, Brazil

*Correspondence:

Marit Ulvik

marit.ulvik@uib.no

Specialty section:

This article was submitted to

Teacher Education,

a section of the journal

Frontiers in Education

Received: 29 January 2020

Accepted: 19 March 2020

Published: 30 April 2020

Citation:

Ulvik M (2020) Promoting

Aesthetical Values to Education.

Front. Educ. 5:34.

doi: 10.3389/feduc.2020.00034 to certain subjects. A main concern in the article is how to include aesthetics in academic subjects. Every subject has elements of emotions, intuition and interpretation and might make use of symbolic forms. The aesthetical involves knowledge that is gained through the senses and that appeals to emotions. An aesthetic approach might contribute to interest and meaning, preconditions for learning that transforms the individual. It might open up unrealized knowledge and unexpected outcomes. Furthermore, the approach might contribute to a good life. The argumentation in the article will build on theory as well as on empirical research from upper secondary school.

Keywords: aesthetics, human development, transformative learning, the art of teaching, comprehensive education

\section{THE STARTING POINT}

Once I had a teacher who showed me the way into modern literature. I can still remember the poems we read and the novels we were introduced to in the mother tongue lessons, in this case Norwegian. The teacher's teaching spoke to my heart, not merely to my head. I was not the only one who had this experience. In a natural science programme, but with Norwegian as a compulsory subject, the teacher changed the whole class's somewhat negative attitude toward literature. I for my part had always loved to read and was an uncritical consumer of literature. However, for me the teacher opened a new world within literature and made me much more conscious of quality. I became interested in literature for adults, modern literature, and poetry. Furthermore, I realized that through literature I could get access to knowledge about being a human being and to perspectives very different from my own. Living in the world suddenly became more complex, but also more interesting than before. Through the teacher's commitment and creative teaching, he 
showed a group of youngsters something to which we would not have had access without him. The teacher brought something new to the table, and he gave us what Biesta (2014) describes as the gift of teaching. This school experience is something I have always brought with me as an example of transformative learning, learning that changes you as a person (Jackson, 1986; Illeris, 2015). You walk out of the classroom a different person than the one who entered - with knowledge, skills, or attitudes you did not have before. Your preconceptions are challenged.

Eventually I became a teacher myself, first in school, then in secondary school teacher education at a university. As a result of my own experiences - with my Norwegian teacher, and with some, but not many, other excellent teachers - I have always sought to pave the way for expressions that make an impression on students. Through expressions that might be characterized as aesthetic, I have wanted to provide students with something meaningful that makes a difference in their lives and that makes going to school worthwhile. The intention has been not only to feed students thinking, but also to reach their hearts and appeal to the whole human being (Biesta, 2017). Sometimes, I think I reached my goal, but many times I did not. Time pressure makes it easy to follow routines. Furthermore, a challenge with transformative learning is that it is difficult to plan for and it is impossible to predetermine students' outcome. What works for some students might not work for others.

The aim of teaching, as I see it, is not only to help students perform well in school; schools are, as Eisner (2002) points out, also places to live together with others and a medium for growth. School occupies a lot of time in young peoples' lives and attention should not only be directed toward the future, but also toward what happens here and now. Furthermore, what is important is not only what people know, but also who they are and how they will use their knowledge. Consequently, teachers need to pay attention both to measurable outcomes as well as to students' human development, something that is difficult to translate into predictable outcomes. Human development is a process, an interaction between the individual and the culture the individual is part of Klafki (2001). It is not about self-realization, but about making the world a better place.

Today there is a pressure on schools to meet the requirements of a knowledge-based global economy (Ball, 2012). International tests like PISA (Programme for International Student Assessment) and TIMMSS (Trends in International Mathematics and Science Study) have had a considerable impact on education. These kinds of tests that measure student outcomes seem to constitute the basis for educational changes. So-called basic skills are emphasized while programmes in arts and humanities are given a lower priority (Nussbaum, 2009). Some researchers claim that human development as well as critical thinking and imagination are neglected (Eisner, 2002; Nussbaum, 2009; Biesta, 2017). However, it is still expected that students are able to use their knowledge in new and creative ways to ensure economic growth (Brekke and Willbergh, 2017). Consequently, even if aesthetic subjects are cut, there is a growing interest in aesthetic methods.

In the following, I will argue for the value of the aesthetic dimension as a way to foster human development in teaching. My reason for this approach is not to promote economic growth, but to support independent thinking and imagination. These are crucial qualities in a democracy (Klafki, 2001; Biesta, 2006). In the argumentation, I will draw on theory as well as some illustrating examples and results from my own empirical studies from upper secondary school.

\section{THE AESTHETIC DIMENSION OF TEACHING}

Aesthetics, from Greek aisthetikos, is knowledge that pertains to the senses and involves how we experience ourselves and the world. The opposite, an-aesthetikos, is what we have in the concept anaesthesia, which is about being unconscious. Aesthetics can thus be connected to being awake and present. Aesthetic expressions can be communicated through symbolic forms like theatre, dance, poetry, and images. These forms represent an interpretation of the world and affect feelings they express how the world is experienced and invite a response. The aesthetical contains a comprehensive understanding of what it is to be a human being, and might be an alternative and a supplement to what is measurable. It gives access to dimensions outside the domain of logic and expresses what is indescribable through verbal language (Austring and Sørensen, 2006). Østergaard (2013) regards aesthetic impressions as something that speaks directly to the senses. Furthermore, aesthetics is defined as a perceptible symbolic form that communicates from, to and about feelings (Austring and Sørensen, 2006, p. 68). To explain: When someone expresses something in a passionate way, they might grip the listener's feelings, and through the way they communicate, they also express their own feelings related to the topic. In that way they both share an experience about feelings.

Austring and Sørensen (2006) present three ways to acquire knowledge: the empirical, the aesthetical and the discursive. The empirical way of learning concerns how human beings sense the world through tasting, smelling, listening, seeing and feeling. Knowledge is bodily anchored and often becomes tacit. This way of learning is especially visible among small children. The aesthetical way of learning builds on the empirical but involves an interpretation in which people elaborate and communicate their experience of the world. Children, for example, might use play or drawing as a way to interpret and elaborate experiences. Teenagers might express experiences through music, poetic language, images, or even in the way they dress. The aesthetical way of learning can also include an interpretation of other people's expressions. Aesthetical learning has to do with how life is experienced, how it feels and is perceived. The individual tries to understand how it is to be a human being. The understanding is mediated through different symbolic forms that give access to varied interpretations and outcomes that cannot be pre-planned. Who can predict the outcome of reading Hamlet (McKernan, 2010)? The discursive way of experiencing the world is the intellectual way of learning, characterized by logical thinking, analysis and discursive use of language. It builds on the two other approaches but involves an abstract understanding. In school, problems with meaning will arise if the discursive way 
of learning is not connected to the other forms. Students might need to experience a phenomenon or be provided with illustrative examples in order to grasp abstract and generalized knowledge.

If the aesthetic is neglected in schools, society will lose valuable human qualities (Eisner, 2002). As expressed in a UNESCO document, "[c]ulture and the arts are essential components of a comprehensive education leading to the full development of the individual" (UNESCO, 2006, p. 3). The document problematizes a growing divide between cognitive and emotional processing and states that education through and in the arts might stimulate cognitive development. In the U.S., Nussbaum (2009) is critical of a situation in which although the liberal arts are part of college and university curricula, it is the demands of the global market that influence the curricula at lower levels. The humanities and the arts are seen as useless for economic profit. However, here I will underline that the aesthetic does not need to be connected to certain subjects. All subjects can be perceived in a sensitive way and include elements of feelings, intuition and interpretation (Løvlie, 1990). For example, art can be used in academic subjects either to illustrate a content or to offer a qualitative different understanding of a phenomenon. The iconic photo of the napalm girl from the Vietnam War might provide a deeper understanding of war than a textbook description does. Furthermore, education can learn from the arts forms of thinking. One lesson to learn is to formulate aims without clearly defined ends, another that form and content are often inextricable (Eisner, 2004). Finally, teaching in itself can be perceived as art. "Art" is in this article understood in a broad manner. When there are no fixed outcomes, there is space for students' interpretations and for creative approaches. Students form their own understanding, and knowledge becomes internalized. According to Brekke and Willbergh (2017), aesthetic ways of learning, in and through the arts, can contribute to autonomy through the aspects of freedom, imagination and development.

In the following, I will argue why the aesthetic dimension should be included in education through four interconnected and overlapping points:

The aesthetic dimension can:

- contribute to human development and in-depth learning

- create interest and meaning for all students

- present different forms of knowledge

- support teaching as an art

\section{Human Development and In-Depth Learning}

Human development is a matter of becoming a wise person and a good citizen. However, what it means to be human today is not prescribed (Biesta, 2006). Based on the situation in the world, with climate challenges, poverty, hunger, and wars, we can ask what young people need in order to manage life in a sustainable way and how education can contribute. In order to overcome these common international challenges, it does not seem adequate only to focus on predetermined outcomes or cultural tools from previous generations. It is impossible to predict what will be useful in the future, and "[i]f we are always aiming at pre-specified ends then we can never grow," as McKernan (2010, p. 8) states. Education therefore needs to support creativity and independent thinking.

Furthermore, in order to act, people have to feel that the situation in the world concerns them and is part of their responsibility, not only know about it theoretically. For that to happen, one needs to be gripped by a content (Klafki, 2001). Consequently, human development requires in-depth learning and that includes more than the cognitive dimension. This means that teachers have to slow down and take their time (Biesta, 2017) - they cannot introduce too many topics but have to be selective. If someone wants to learn all languages, he or she ends up learning none (Nussbaum, 1997). When selecting what to introduce in schools, Klafki (2001) suggests emphasizing key contemporary issues which are dynamic and not fixed.

Nussbaum (2009) differentiates between education for profit and education for freedom and global citizenship. She states that today's programmes favor cultivation of the technical and claims that: "the humanities and the arts make a world that is worth living in, people who are able to see other human beings as equals, and nations that are able to overcome fear and suspicion in favor of sympathetic and reasoned debate" (Nussbaum, 2009, p. 13). Considering an unsecure future, critical thinking, imagination, and creativity likely will be important attributes to encourage. Including an aesthetic way of learning in schools might support and develop these qualities. Furthermore, aesthetic expressions like music, poetry and images are something that offer people joy and that might enrich their lives, not only their education.

Education in is itself no guarantee for human behavior. The letter below expresses in a strong way that education can be misused $^{1}$ :

\section{Dear Teacher:}

I am a survivor of a concentration camp. My eyes saw what no man should witness:

Gas chambers built by learned engineers.

Children poisoned by educated physicians.

Infants killed by trained nurses.

Women and babies shot and burned by high school and college graduates.

So, I am suspicious of education.

My request is: Help your students become human. Your efforts must never produce learned monsters, skilled psychopaths, educated Eichmanns.

Reading, writing, arithmetic are important only if they serve to make our children more human.

The letter articulates the point that people can be clever without being wise - or human. How can we avoid what is described in the letter? How can schools contribute to humanity? The German philosopher Adorno (1988) stated in 1966 in a radio programme with the title: "Upbringing after Auschwitz" that empathy and independence are crucial characteristics to encourage and promote in schools. Opening up to empathy implies that there needs to be a space for feelings and for concern for the others. To understand other

\footnotetext{
${ }^{1}$ https://www.facinghistory.org/holocaust-human-behavior/education-and-
} future 
people's feelings, one needs access to one's own. Furthermore, if students are only encouraged to do what they are told, their own critical thinking and imagination might not be developed. The discursive way of learning that often takes place in schools needs to be supplemented by aesthetic and empirical approaches (Austring and Sørensen, 2006).

\section{Create Interest and Meaning for All Students}

Initially I described, through an example, what I perceived to be transformative learning - learning that supported my human development and changed me as a person. However, transformative learning cannot be taught. What teachers can do is to promote the likelihood that transformative learning takes place (Illeris, 2015). Catching students' interests might be one way to go. Van Manen (1991) emphasizes the importance of interest as a precondition for learning, to be intensively present for something or someone. Interest cannot be demanded, but can be caught when something appears meaningful, which is different from being entertaining. Content might be conceived as meaningful by students through the teacher's professional "guessing" about how the curriculum and students' life-worlds can be brought together (Willbergh, 2015). This way of encouraging transformative learning demands teachers who know their subject as well as their students.

Furthermore, in order to have an impact on young people, teaching needs to appeal to diverse dimensions. Illeris (2015) mentions three dimensions that exist in all learning: a cognitive, a social, and an emotional dimension. Especially the latter, the one that can be connected to aesthetics, is, in my opinion, neglected in teaching today. What cannot be counted tends not to count (McKernan, 2010). The Norwegian philosopher Naess (2010) claims that in order to make an impression on students, education needs to grip their feelings and be characterized by amazement, creativity, and imagination. Management by objectives might lead to underestimation of the role of feelings. According to McKernan (2010), the objectives model is satisfactory for training or instruction but fails when applied to education. The aesthetic approach - to use artistic expressions as a pedagogical method - offer an empowering impact by opening up alternative understandings and a diversity of forms.

Here I will include an example from when I visited a student during her practice placement (Ulvik, 2018). Åse taught a lesson in a year-eight class (14-year olds) about how different animals were adapted to different biotopes. She presented a very wellstructured PowerPoint with few, but important, points and had included in her oral presentation the main concepts the students were supposed to learn. However, after the lesson Åse said that she felt that the students put her on mute. She concluded that she had chosen the wrong channel and had to choose a different one to reach the students. She decided to repeat the lesson, but this time to make use of what she had learned about aesthetics in her teacher education programme. Now she only put spectacular images into her PowerPoint, and told exciting stories about the animals, rather than merely presenting facts. The students were hooked and prepared for learning in a more discursive way. Åse thought that many students had negative learning experiences in science, her teaching subject. She explained that in a way she tricked them into the idea that learning in science was not that hard.

While verbal utterances provide unambiguous, but thin, information, images - the form Åse chose - are ambiguous and provide rich information (Kjeldsen, 2015). The richness in a picture might provide a fuller and more emotional understanding of something, and it gives students more freedom and space for imagination. Furthermore, images might support students with limited language abilities and utilize their knowledge about the world (Moses, 2015). In that way more students get access to knowledge. In addition to images that provide a different epistemological understanding than words (Kjeldsen, 2015), Åse introduced narratives about the animals. Narratives might awaken emotional involvement more than other forms (Gravett et al., 2017). Using different forms of representation than the discursive one, Åse offered her students an alternative entrance to the topic.

A perception of intelligence as verbally-transmitted knowledge might not recognize students with other talents than those the school usually nurtures (Eisner, 2004). Students can be smart in different ways, as Gardner (2006) points out in his theory about multiple intelligences. Schools should consequently involve different approaches and address the whole human being. Furthermore, in order to be creative, the different parts of the brain need to interact. While the right part can be linked to the aesthetic dimension, the left part can be linked to the discursive way of learning (Austring and Sørensen, 2006). It is easy to forget what Malaguzzi (1993) expresses in his "Poem about hundred languages" (see two excerpts from the poem below):

\author{
The child has \\ a hundred languages \\ but they steal ninety-nine. \\ The school and the culture \\ separate the head from the body. \\ They tell the child: \\ to think without hands \\ to do without head \\ They tell the child: \\ that work and play \\ reality and fantasy \\ science and imagination \\ sky and earth \\ reason and dream \\ are things \\ that do not belong together.
}

\section{Present Different Forms of Knowledge}

Like the poem above suggests, there are different forms of knowledge, and therefore different representations - as shown in Åse's example. A famous dancer once said that if she could put something into words, she did not have to dance it (Østergaard, 2013). Eisner (2002) claims that "...to use new tools and new forms of representation enables us to look for different things 
and to ask new questions" (p. 380). Coherent education should include both head, hand and the heart - the intellectual, practical and emotional (Klafki, 2001). Østergaard (2013) makes a similar point. He states that to be able to describe and explain nature has become the main issue in natural science. In order to support sustainable development, students need to see nature as a value, something that demands alternative representations. $\mathrm{He}$ argues that using the arts might lead to a qualitative access to phenomena. In the famous book about the little prince, it is said: "It is only with the heart that one can see rightly; what is essential is invisible to the eye" (de Saint-Exupéry, 2015, p. 67). In order to understand the value of nature, students need to experience and be gripped by it - to see nature with their heart as well as their minds. Østergaard (2013) concludes that the arts might give a different access to phenomena.

A feature of the arts is that its aims are not fixed; attention is directed toward the particular and the ambiguous. There is room for surprises and for using discretion. The opposite is having fixed measurable aims, attention to what is comparable and uniform, toward exact answers, what is predictable and unambiguous and follows rules. Eisner (2004), who has written about what education can learn from the arts, does not suggest that education should not include measurable aims, but that there should be a balance among descriptive, problem-solving and expressive aims (Eisner, 1985). We need them all, but today the measurable aims seem to take precedence.

\section{Teaching as an Art}

Teachers' work might itself have an aesthetic quality. According to Eisner (2002): "Good teaching depends upon artistry and aesthetic considerations" (p. 382). He compares teaching with playing jazz. One needs to know when to come in and take the lead, when to bow out, and when to improvise. These aspects follow no rule, they need to be felt. What happens in the classroom is partly informed by theory, but also by improvization in real time on the spot (Bergum, 2003; Eisner, 2004). The form and content depend on who the players are, and improvization therefore depends on each person finding their own voice rather than doing what is "right" (Bergum, 2003). When writing about transformative teaching, Jackson (1986) uses the potter as a metaphor to describe teachers as artists. Even if there are no recipes that tells teachers how to bring on changes, he suggests three ways. One is to be a role model, the second is mild persuasion and the third is to use narratives. The German philosopher Bollnow (1969) problematize whether it is possible to change another human being in a profound way, and he describes upbringing as a risky undertaking. Even if I argue that the aesthetic dimensions should be included in teaching, I will also add that it might lead to unintended outcomes that we should be aware. Human beings are not objects.

Moreover, a lesson might have a dramaturgy (Dale, 1993). It is about the rhythm, the atmosphere, the balance between elements and how the lesson is perceived as a varied whole. Good teaching transmits knowledge in a way the students understand and that encourages their interests. It is an interplay between teacher and students that cannot be replaced by online lectures in which knowledge seems more like a product to be delivered.

\section{EMPIRICAL RESEARCH ON AESTHETIC LEARNING}

So far, my arguments are built on theory. In this part I will include examples from my own empirical studies (Ulvik, 2020a,b). With a rather negative impression of the variety of representations used in schools, some colleagues and I investigated how students in upper secondary school perceive school. Through 14 focus group and conversations with 84 students we wanted to learn more about when the school promoted human development and interest in learning, qualities that Norwegian schools are required by law to support (Education Act, 2014, \$1). We also arranged three focus groups with four secondary school teachers in each group, asking them to tell us about how they promote interest among students.

The results show that both students and teachers value varied teaching and experiences that appeal not only to the cognitive dimension, but also to the practical and emotional. One of the main categories in the students' answers related to the aesthetic dimension. In the following I will include examples especially from this dimension, examples that illustrate how students learn through the arts (understood in a broad sense) and how that creates interest (Kvam and Ulvik, 2019; Ulvik, 2020b):

I had a teacher in Norwegian who showed art works and played music when he taught about different periods in literature. The periods came to life and I can therefore still recognise characteristics. I can look at art works and say: oh, that is from that period.

We saw a film about taking care of the environment and about sustainability. [... I I do not eat red meat anymore, so the film actually changed me.

Sometimes our Spanish teacher plays a song we are supposed to translate or understand the meaning of. Then we learn through music. It's great fun.

Instead of learning about all the grammatical rules, she told us about German culture, how it is, what they eat.

Here students learn through images, music, film, and storytelling. The need for variation is underlined, for instance in the following example: "Once they (the teachers) do something different it becomes much more interesting and engaging."

Students complain about time and assessment pressure and state that in upper secondary school they primarily learn for the test, and that there is often no time to get interested. A student said that: "My ideal school is a school where the teachers in their teaching considering different needs and how students learn in different ways."

The students also described how they appreciate committed teachers that manage to spark a light: "Even if they (the teachers) talk about something boring and heavy, they are so engaged that you look forward to listening to them."

Students value aesthetical impressions, but also being allowed to express themselves in an aesthetic way. One of the focus groups explained that they once were allowed to present some group work as theater. Some students suggested presenting material through a film: 
It would have been good fun to make a film! A short film that you can present to the rest of the class. On pollution, for instance. We could walk around, film different places, like the media does! Our creativity would have blossomed!

Examples like the above are rare in upper secondary school. It can be added that in upper secondary school, aesthetic subjects like music, art or drama are not common subjects in the national curriculum. However, what was underlined by the students supports the idea about different ways of acquiring knowledge. "We got a different understanding of a fish when we saw a fish in real life," one student said. Another student mentioned that "in biology we had a field excursion, and everyone became engaged even though it was a heavy topic. But we learned in a practical way."

The teachers, on their side, supported the idea that discursive teaching needs to be supplemented with aesthetic and empirical learning. They suggested among others role-plays and bringing in relevant objects:

I like to include role-plays in my subjects. Then the students get a more visualised understanding of the topic.

In history I like very much to use props. Through the years, I have collected quite a selection. For example, when they learn about the nineteenth century, I might use a caricature drawing from 1897 and ask the students: 'What can it tell us?'

The teachers emphasized appealing to the emotions. One teacher elaborated on this view: "Students should take something home from the lessons, so to appeal to their feelings might be important." He described how his science class arranged a role-play in groups about a young couple who were expecting a baby and were discussing whether or not to take a genetic test. The couple was offered a test because they had a disease in the family. The teacher experienced how the groups became very engaged and continued the discussion after the lesson.

The teachers in our study, mainly from upper secondary school, really wanted to stimulate students' feelings and vary their teaching. However, like the students, they underlined the assessment pressure and how there is often not enough time for students to get interested.

Even if the teachers saw some opportunities for creating interest and meaning, they found that there are sometimes too many topics to cover or a lack of time to plan lessons that make an impression on students. The teachers highlighted that in an ideal school teachers should cooperate, and they would also have liked to do interdisciplinary projects where they could draw on each other as a way to get students interested. Such projects might be more compliant with life outside school, according to the teachers.

Norwegian teachers are expected to promote human development. It might be a challenge, but nevertheless meaningful as expressed by one of the teachers:

It is very demanding to be a teacher and all the time try to provide students with lasting experiences, experiences that contribute to human development. It is a demanding enterprise, but at the same time, it what makes it so great to be a teacher.

The present study shows that through aesthetic approaches and committed teaching, students are inspired to learn, and to learn more than facts. They also get an emotional involvement with their learning that might transform them as human beings. For that to happen, students need varied representations within their subjects. They also want more creative subjects, like music, dance and fine arts. The aesthetic dimension will add an extra dimension to students' learning. One student explained:

I think society is almost a bit afraid to include subjects like that. They are concerned about the next generation getting enough knowledge, but creative subjects are important! A lot of good thought can come out of it, and you can use your creativity. It's transferrable to other, more factbased subjects.

For the future, society needs creative people, not only people who can repeat what we already know. Consequently, there should be space for what cannot be measured and that gives student freedom and room for imagination. Freedom is best cultivated by an education that supports critical thinking. Sometimes including different representations does not require big changes, but rather a change of attitude - like in Åse's example.

\section{IMPLICATIONS}

A key argument for including the aesthetic dimension in education is to support human development. The previous quoted letter points out that the connection between education and wisdom is not self-evident. Encountering global challenges today, there is a need for global citizenship and for human beings that feel responsible and can imagine a way forward. However, human development through education is not an easy route to stake out. Transformative learning cannot be planned for and be evaluated in terms of measurable outcomes. Furthermore, we do not know what knowledge and skills are needed in the future, and what is needed is therefore creative and independent thinkers. However, while McKernan (2010) states that the objectives model fails when it comes to education, education in Europe has become more standards driven. This is a result of the so-called Bologna Agreement, through which European countries have tried to ensure comparability in the standards and qualities of higher education. It is debatable whether the agreement encourages aesthetic qualities in education.

Moreover, I have argued that the aesthetic dimension is part of all subjects. This means that it is not something that only should be offered in separate courses or at certain levels in the educational system. In higher education, students become included in a special field, and often learn by the discursive way. However, to get a deep understanding 
of their topics, they might need examples and experiences. Moreover, education is not only about fitting in to a community, but also involves thinking critically about and even adding to existing knowledge. As such there should be space for students to create their own interpretations and to elaborate on what they have learned in different ways. The aesthetic approach might offer this space for interpretation and processing.

I will point to three consequences for education that includes the aesthetic dimension in addition to the empirical and discursive. An aesthetic approach will have consequences for: (1) the quality of teaching, (2) the resources students are offered, and (3) what students are asked and allowed to do. In the following I will elaborate on these points.

Firstly, aesthetic teaching has a dramaturgy and appears as a meaningful whole (Dale, 1993). There is room for improvizations and for varied expressions. Examples here can be images, films, excursions, narratives and poetic language. These are forms that could also be included in upper secondary school and in higher education. However, I have to add that I find the quality of the different forms important. An artistic image might offer a range of interpretations, and more so than a quick and random choice from the internet. Furthermore, teachers who bring something new to the table have to know their subject but also be willing to take a risk. When stepping out of their comfort zone and putting themselves at risk, there is no guarantee of success. Aesthetic expressions can open up and inspire, but the outcome can never be predetermined. Through professional "guessing," teachers can choose something they think will promote transformative learning (Brekke and Willbergh, 2017).

Secondly, the resources students are offered can also have an aesthetic quality that appeals to more than the cognitive dimension. In some disciplines, students are offered empirical experiences, for example in laboratories, excursions, or practice placements. Sometimes these experiences have an aesthetic value as well. A biology student might appreciate the beauty of a flower. Student teachers might be gripped by experiences from the classroom. However, academic language might often be perceived as boring, and academic texts seldom appear vivid and absorbing. While a good lecture can be engaging, moving, and transformative, textbooks and articles seldom are. The question is whether the traditional academic form only presents part of academic knowledge, and whether the knowledge should be presented in varied ways. For example, do the poetic sections and the narratives in my text add to the understanding of aesthetics in education? That will be up to the reader to judge.

Thirdly, including the aesthetic dimension might also have consequences for students' assignments and exams. Is there room for drawings, role-plays and using their bodies? In the focus groups mentioned previously, many of the groups characterized their schooling as life on a chair. Are students allowed to include aesthetic elements in their presentations, such as making a film? Time pressure will sometimes be an excuse for not including varied presentations. However, speed is not something that encourages deep learning. Furthermore, sometimes students prefer what they are used to and make them feel safe, with fixed answers. In the postgraduate teaching programme of which I am part, students have an assignment in which they have to include an aesthetic element in their presentation. Many students feel insecure and out of their comfort zone, but they enjoy seeing all the different presentations from their peers and in the end often find the assignment useful. When later in the term students have to conduct action research in their practice placement, many choose to try out something related to aesthetics. Could exams include varied forms? In our teacher education, we once tried out a portfolio with five assignments in which students were allowed to use varied forms of representations. However, the external examiners found it difficult to assess, and we decided to give it up out of consideration for the students.

\section{CONCLUSION}

The value of aesthetics lies among other things, in the support it provides for critical thinking and creativity, characteristics that are important for encountering an unknown future and for developing democracy. Moreover, aesthetics might contribute to a good life. Aesthetic learning challenges the prevailing concept of knowledge in secondary school and in higher education. Furthermore, it raises the question of the purpose of education, whether it should be for freedom or for profit. Today the economic organization OECD plays a leading role in school development in Europe, and economic growth seems to be a guiding principle for educational change. Policy documents highlight the importance of innovative and creative thinking both when it comes to growth and well-being (OECD, 2019). However, there is a tension between combining innovative and creative thinking with the objectives model in which education is broken down into measurable targets. Aesthetic learning might open up for unrealized knowledge and unexpected outcomes that cannot be predetermined and that can be difficult to measure. In the end, what education should be about boils down to what kind of people we want to educate in what kind of society.

\section{ETHICS STATEMENT}

The studies involving human participants were reviewed and approved by NSD - Norwegian Centre for Research Data. The patients/participants provided their written informed consent to participate in this study.

\section{AUTHOR CONTRIBUTIONS}

The author confirms being the sole contributor of this work and has approved it for publication. 


\section{REFERENCES}

Adorno, T. W. (1988). Oppdragelse etter Auschwitz. Agora 2, 41-54.

Austring, B. D., and Sørensen, M. (2006). AEstetik og laering. Grundbog om aestetiske laereprocesser. Copenhagen: Hans Reitzels Forlag.

Ball, S. J. (2012). Show me the money! Neoliberalism at work in education. Forum $54,23-28$.

Bergum, V. (2003). Relational pedagogy. Embodiment, improvisation, and interdependence. Nurs. Philos. 4, 121-128. doi: 10.1046/j.1466-769x.2003. 00128.x

Biesta, G. (2014). Receiving the gift of teaching: from 'learning from' to being taught by. Stud. Philos. Educ. 32, 449-461. doi: 10.1007/s11217-012-9312-9

Biesta, G. (2017). Touching the soul? Exploring an alternative outlook for philosophical work with children and young people. Child. Philos. 13, 415-452.

Biesta, G. J. J. (2006). Beyond Learning. Democratic Education for a Human Future. London: Paradigm Publishers.

Bollnow, O. F. (1969). Eksistensfilosofi og pedagogikk. Oslo: Fabritius.

Brekke, B., and Willbergh, I. (2017). Frihet, fantasi og utfoldelse: en kvalitativ studie av estetiske arbeidsformer i laererutdanningene. Nordisk tidsskrift for pedagogikk og kritikk 3, 1-13. doi: 10.23865/ntpk.v3.554

Dale, E. L. (1993). Den profesjonelle Skole. Oslo: Gyldendal.

de Saint-Exupéry, A. (2015). The Little Prince. Saita Publications. Available online at: https://www.openrightslibrary.com/the-little-prince-ebook/Original from 1943 (accessed January 9, 2020).

Education Act (2014). Available online at: https://www.regjeringen.no/en/ dokumenter/education-act/id213315/ (accessed January 9, 2020).

Eisner, E. (2002). From episteme to phronesis to artistry in the study and improvement of teaching. Teach. Teach. Educ. 18, 375-385. doi: 10.1016/s0742051x $(02) 00004-5$

Eisner, E. W. (1985). The Educational Imagination on the Design and Evaluation of School Programs. New York, NY: Macmillan.

Eisner, E. W. (2004). What can education learn from the arts about the practice of education? Int. J. Educ. Arts 5, 1-13.

Gardner, H. (2006). Multiple Intelligences. New Horizons. New York, NY: Basic Books.

Gravett, S., de Beer, J., Odendaal-Kroon, K., and Merseth, K. K. (2017). The affordance of case-based teaching for the professional learning of studnetteachers. J. Curric. Stud. 49, 369-390.

Illeris, K. (2015). Transformative learning in higher education. J. Trans. Learn. 3, 46-51.

Jackson, P. (1986). The Practice of Teaching. New York, NY: Teachers College. Columbia University.

Kjeldsen, J. E. (2015). The rhetoric of thick representation: how pictures render the importance and strength of an argument salient. Argumentation 29, 197-215. doi: 10.1007/s10503-014-9342-2

Klafki, W. (2001). Dannelsesteori og didaktik. Nye studier. Arhus: Forlaget Klim.

Kvam, E. K., and Ulvik, M. (2019). "Students' perspective on teaching. The experience of teaching. Teachers' work in a tension between student perspectives and educational policy," in Paper Presented at European Conference on Educational Research (ECER), Hamburg, Germany.
Løvlie, L. (1990). Den estetiske erfaring. Nordisk Pedagogik 1-2, 1-18. doi: 10.4045/ tidsskr.18.0077

Malaguzzi, L. (1993). Poem About Hundred Languages. Available online at: https:/www.reggiochildren.it/en/reggio-emilia-approach/100-linguaggi-en/ (accessed January 24, 2020).

McKernan, J. (2010). A critique of instructional objectives. Educ. Inq. 1, 57-67.

Moses, L. (2015). The role(s) of image for young bilinguals reading multimodal informational texts. Lang. Lit. 17, 82-99.

Naess, A. (2010). Livsfilosofi. Et personlig bidrag om følelser og fornuft (3.opplag). Oslo: Universitetsforlaget.

Nussbaum, M. C. (1997). Cultivating Humanity. A Classical Defense of Reform in Liberal Education. Cambridge, MA: Harvard University Press.

Nussbaum, M. C. (2009). Education for profit, education for freedom. Liberal Education 95, 6-13.

OECD (2019). Innovation Strategy for Education and Training. Available online at: https://www.oecd.org/education/ceri/ innovationstrategyforeducationandtraining.htm (accessed December 18, 2019).

Østergaard, E. (2013). Naturfag og kunst: berøringer med verden. Bedre Skole 4, $10-15$.

Ulvik, M. (2018). “Å sette avtrykk,” in Marionetteskolen, eds I. E. Taraldsen and E. Kanestrøm (Copenhagen: Gyldendal).

Ulvik, M. (2020a). “Å vaere laerer,” in Skolens Betydning, eds I. M. Ulvik, I. Helleve, and D. Roness (Bergen: Fagbokforlaget).

Ulvik, M. (2020b). "Estetiske erfaringer - hvorfor og hvordan," in Skolens Betydning, eds I. M. Ulvik, I. Helleve, and D. Roness (Bergen: Fagbokforlaget).

UNESCO (2006). Road Map for Arts Education: The World Conference on Arts Education- Building Creative Capacities for the 21st Century. Available online at: http://www.unesco.org/new/fileadmin/MULTIMEDIA/ HQ/CLT/CLT/pdf/Arts_Edu_RoadMap_en.pdf (accessed January 09, 2020).

Van Manen, M. (1991). The Tact of Teaching. The Meaning of Pedagogical Thoughtfulness. Albany, NY: State University of New York Press.

Willbergh, I. (2015). The problems of 'competence' and alternatives from the Scandinavian perspective of Bildung. J. Curric. Stud. 47, 334-354. doi: 10.1080/ 00220272.2014 .1002112

Conflict of Interest: The author declares that the research was conducted in the absence of any commercial or financial relationships that could be construed as a potential conflict of interest.

The handling Editor declared a past collaboration with the author.

Copyright (C) 2020 Ulvik. This is an open-access article distributed under the terms of the Creative Commons Attribution License (CC BY). The use, distribution or reproduction in other forums is permitted, provided the original author(s) and the copyright owner(s) are credited and that the original publication in this journal is cited, in accordance with accepted academic practice. No use, distribution or reproduction is permitted which does not comply with these terms. 